\title{
Pelatihan Pemanfaatan Limbah Sekam Padi pada Siswa SMA Eunterpreneurship Chevalier Anasai Merauke
}

\author{
Martha Betaubun ${ }^{1}$, Henie Poerwandar Asmaningrum², Alexander Phuk Tjilen ${ }^{3}$ \\ marthabetaubun@unmus.ac.id ${ }^{1}$, poerwandar@unmus.ac.id², aphoek@yahoo.com
}

\author{
1,2,3 Universitas Musamus
}

\begin{abstract}
Article History:
Received: 24-10-2021

Revised: 06-01-2021

Accepted: 24-01-2021
\end{abstract}

\begin{abstract}
The absence of assistance and training efforts to the community regarding rice husk waste management is the focus of this PDM program. In this program, students will assist the community in processing rice husk waste into various products that can be used alone or sold again so as to improve the community's economy. The target of this activity is ECA High School students, the majority of whom are indigenous Papuans. Rice husk waste is processed into briquettes and planting media that can be used alone or sold again to improve the lives of students and the community. This program is able to increase the knowledge and ability of the community in processing rice husk waste, which has an impact on improving public health and education as well. In addition, this program will provide new knowledge insights for students, as well as trigger students' critical attitude and creativity in solving problems in the surrounding community.
\end{abstract}

\section{Pendahuluan}

Kampung Matara merupakan salah satu kampung yang terletak di Distrik Semangga, Kabupaten Merauke. Terdapat dua dusun yang berada di dalam wilayah Kampung Matara, yakni Dusun Matara dan Dusun Anasai. Mata pencaharian masyarakat Kampung Matara pada umumnya adalah nelayan dan petani. Hal ini disebabkan karena posisi kampung yang terletak di pesisir Kali Maro, tepi Laut Arafura.

Dusun Anasai memiliki potensi sebagai penghasil padi. Selain potensi hasil sawah berupa padi, perlu juga diperhatikan potensi limbah sebagai hasil samping pada proses pasca panen. Pada setiap penggilingan padi akan selalu dihasilkan tumpukan bahkan gunungan sekam yang semakin lama semakin tinggi. Saat ini pemanfaatan sekam padi tersebut masih sangat sedikit, sehingga sekam menjadi limbah yang mengganggu lingkungan. Proses penghancuran limbah secara alami berlangsung lambat, sehingga limbah tidak saja mengganggu lingkungan sekitarnya tetapi juga mengganggu kesehatan manusia.

Petani di Dusun Anasai biasanya membakar sekam padi di tempat terbuka seperti di sawah-sawah yang mengakibatkan pencemaran lingkungan berupa emisi gas hasil pembakaran seperti $\mathrm{CO}$ dan $\mathrm{CO} 2$. Hal ini dapat meningkatkan jumlah polutan dalam udara dan dapat menggangu kesehatan masyarakat. Namun, bila sekam dimasukkan ke dalam 
tanah sawah, akan mengganggu pertumbuhan padi karena sekam mengandung lignin dan selulosa yang cukup besar yang tidak dapat langsung terurai di dalam tanah sehingga menurunkan produktivitas padi.

Sekam padi berupa lapisan keras yang meliputi kariopsis yang terdiri dari dua bentuk daun yaitu sekam kelopak dan sekam mahkota, dimana pada proses penggilingan padi, sekam akan terpisah dari butir beras dan menjadi bahan sisa atau limbah penggilingan. Proses penghancuran limbah secara alami berlangsung lambat, sehingga tumpukan limbah dapat mengganggu lingkungan sekitarnya dan berdampak terhadap kesehatan manusia. Padahal, melalui pendekatan teknologi, limbah pertanian dapat diolah lebih lanjut menjadi hasil tambahan di samping produk utamanya yaitu sekam (Admin, 2021).

Menurut Jasman (2011) sekam mengandung beberapa unsur penting yakni kadar air $(9,02 \%)$, protein kasar $(3,03 \%)$, lemak $(1,18 \%)$, serat kasar $(35,68 \%)$, abu $(17,17 \%)$, dan karbohidrat dasar $(33,71)$. Selanjutnya komposisi kimia sekam padi menurut DTC-IPB sekam mengandung karbon (zat arang) sebesar 1,33\%, hidrogen sebesar 1,54\%, oksigen 33,64\%, dan silika sebesar $16,98 \%$.

Komposisi kandungan tersebut, sekam dapat dimanfaatkan untuk berbagai keperluan diantaranya sebagai bahan baku pada industri kimia terutama kandungan zat kimia furfural yang dapat digunakan sebagai bahan baku industry kimia, sebagai bahan baku industri bangunan, terutama silika (SiO2) yang dapat digunakan untuk campuran pada pembuatan semen Portland, bahan isolasi, husk-board dan campuran pada industri bata merah, sebagai sumber energi panas pada berbagai keperluan manusia, kadar selulosa yang cukup tinggi dapat memberikan pembakaran yang merata dan stabil (Handayani et al., 2014).

Sekam memiliki kerapatan jenis (bulk density) $1125 \mathrm{~kg} / \mathrm{m} 3$, dengan nilai kalori $1 \mathrm{~kg}$ sekam sebesar 3300 kkalori. Menurut Houston (1972) sekam memiliki bulk density 0,100 g/ $\mathrm{ml}$, nilai kalori antara 3300-3600 kkalori/kg sekam dengan konduktivitas panas 0,271 BTU. Untuk lebih memudahkan diversifikasi penggunaan sekam, maka sekam perlu dipadatkan menjadi bentuk yang lebih sederhana, praktis dan tidak memakan tempat, yaitu bentuk arang sekam. Arang sekam memiliki fungsi mengikat logam berat. Selain itu arang sekam berfungsi untuk menggemburkan tanah sehingga bisa mempermudah akar tanaman menyerap unsur hara di dalamnya (Agung et al., 2013). Hasil analisis komposisi kimia arang sekam padi menunjukkan kandungan silika (SiO2) sekitar 90-99\% dan sejumlah kecil alkali dan logam pengotor ( Houston, 1972).

Berdasarkan observasi dan wawancara terhadap beberapa masyarakat Dusun Anasai diketahui beberapa permasalahan berikut :

1) Sebagian besar masyarakat belum pernah mendapat pelatihan tentang pemanfaatan 
limbah sekam padi

2) Masih rendahnya kreatifitas masyarakat dalam mengolah limbah sekam padi

3) Keinginan aparat kampung untuk meningkatkan pendapatan masyarakat namun terkendala modal dan pemasaran

Potensi pemanfaatan limbah sekam padi ini belum dikelola secara baik oleh aparat kampung setempat. Jika limbah sekam padi dikelola oleh masyarakat, maka akan dapat meningkatkan produktivitas petani dan masyarakat pengelola limbah sekam padi tersebut. Hal ini akan berdampak pada peningkatan taraf hidup masyarakat kampung secara keseluruhan. nilai ekonomi limbah tersebut dalam kehidupan masyarakat Dusun Anasai.

\section{Metode}

Dalam kegiatan ini dilibatkan 3 orang dosen sebagai koordinator kegiatan, 1 orang narasumber, 6 orang mahasiswa. Keterlibatan mahasiswa dalam kegiatan ini bertujuan untuk memberikan pengalaman sosial kepada mahasiswa dan juga agar tujuan kegiatan dapat dicapai secara optimal. Peserta kegiatan ini adalah siswa SMA ECA (Entrepreneurship Chevalier Anasai) kelas $X$ sebanyak 25 siswa. Kegiatan dilakukan pada bulan Agustus September 2021 di SMA ECA yang beralamat di Jalan Raya Kuprik Kumbe, Matara, Kecamatan Semangga, Kabupaten Merauke, Propinsi Papua.

Pelaksanaan program terdiri dari observasi, kegiatan inti, dan evaluasi. Berikut penjelasan tahap-tahap pelaksanaan program

\section{Observasi}

Pada tahap ini dilakukan observasi dan koordinasi dengan Kepala sekolah SMA ECA Merauke. Hal-hal yang perlu disepakati adalah penentuan tempat dan waktu pelaksanaan program. Serta pendataan siswa yang mengikuti program.

2. Kegiatan inti

a. Sosialisasi

Pada tahap ini, tim PDM memberikan sosialisasi dan pengetahuan awal tentang kegiatan yang akan dilaksanakan meliputi latar belakang, manfaat, dan rencana tindak lanjut program. Pada tahap ini juga disampaikan bahwa akan dilakukan transfer ipteks sebanyak 3 macam cara memanfaatkan limbah sekam padi.

b. Pelatihan

Pada tahap ini dilakukan pelatihan atau transfer ipteks dalam memanfaatkan limbah sekam padi. Transfer ipteks tersebut berupa pelatihan-pelatihan yang berkaitan dengan pemanfaatan limbah sekam padi serta pendampingan kepada siswa melalui mahasiswa.

c. Pendampingan

Selama kegiatan inti masyarakat peserta program akan didampingi oleh dosen dan mahasiswa. Sehingga tujuan program dapat tercapai dengan baik dan tepat waktu. 


\section{Evaluasi}

Evaluasi program dilakukan sejak awal program berjalan hingga akhir. Untuk mengetahui ada tidaknya pemahaman masyarakat terhadap penerapan ipteks yang dilakukan dalam program, maka dilakukan uji pretes dan postes. Selain itu diberikan angket tanggapan siswa terhadap program yang dijalankan.

\section{Pembahasan}

Pada tanggal 25 Agustus 2021 tim dosen melakukan survei dan koordinasi dengan Kepala Sekolah SMA ECA Merauke. Dalam tahap ini disepakati waktu pelatihan dan pendampingan kegiatan kepada siswa, yakni setiap hari sabtu selama 1 bulan. Hal tersebut dikarenakan sistem SMA ECA adalah sistem asrama. Sehingga pada hari Senin - Jumat aktivitas siswa telah diatur dari pukul 05.00 WIT hingga 20.00 WIT. Sedangkan hari Sabtu cenderung merupakan hari bebas dimana siswa dapat melakukan aktivitas lainnya namun tetap dalam pegawasan guru. Selanjutnya dilakukan persiapan untuk pelaksanaan kegiatan berikutnya seperti pembuatan spanduk, pembuatan modul, seminar kit, bahan-bahan pelatihan, instrumen pretes dan postes, dan instrumen respon siswa.

Pada tanggal 11 September 2021 dilakukan kegiatan sosialisasi pada siswa. Pada tahap ini, tim dosen memberikan sosialisasi terkait kegiatan yang akan dilaksanakan. Sosialisasi meliputi tujuan kegiatan, waktu kegiatan, tahap-tahap kegiatan, dan evaluasi kegiatan.

Pada tanggal 11, 18, dan 25 September 2021 dilakukan pelatihan dan pendampingan kepada siswa. Rincian bahan, alat, dan prosedur dijelaskan berikut ini :

1) Arang sekam sebagai media tanam

Pembuatan arang sekam sebagai media tanam memerlukan 2 proses tahapan. Proses pertama adalah membuat alat untuk membakar sekam padi (cerobong). Proses kedua adalah pembuatan arang sekam padi.

a. Proses pertama, pembuatan cerobong

Bahan dan alat:

- Seng ukuran $70 \times 150 \mathrm{~cm}$

- Kawat untuk mengikat

- Paku besar (paku usuk)

- Palu

- Meteran

\section{Cara pembuatan :}


- Lubangi seng yang sudah disiapkan dengan jarak kurang lebih $10 \mathrm{~cm}$ antar lubang, yang dilubangi hanya setengah atau diarea $70 \times 100 \mathrm{~cm}$. Lubang ini berfungsi untuk membuang panas dari bahan bakar ke tumpukan sekam padi, tanpa harus membakar sekam secara langsung.

- Setelah selesai membuat lubang pada seng, gulung seng tersebut sehingga menjadi seperti cerobong asap, ikat kuat-kuat dengan kawat. Maka cerobong yang dihasilkan akan berukuran tinggi $150 \mathrm{~cm}$.

- Sisi bawah dilubangi $100 \mathrm{~cm}$, lubang tersebut bertujuan untuk perantara api

b. Proses kedua, pembuatan arang sekam padi

\section{Bahan dan alat:}

- Sekam padi yang kering, sebagai bahan dasar.

- Cerobong, sebagai media pembakaran sekam.

- Kayu api, sebagai bahan bakar pada proses pengarangan sekam.

\section{Cara pembuatan:}

- Siapkan sekam padi, serabut kelapa atau kertas koran, sapu lidi, korek api dan sedikit minyak tanah. Pilih lokasi pembakaran yang jauh dari perumahan atau jalan, karena proses pembakaran sekam padi akan menimbulkan asap yang tebal. Sebaiknya alas tempat pembakaran terbuat dari lantai keras yang tahan panas, atau alasi bagian bawah dengan plat seng sebelum melakukan pembakaran. Hal ini untuk memudahkan pengambilan arang sekam.

- Berdirikan cerobong di tanah yang rata dan beri penyangga di sekitar cerobong agar bisa berdiri dengan tegak dan kuat.

- Masukan serabut kelapa atau Koran pada lubang cerobong.

- Tuangkan sekam padi yang sudah disediakan di sekeliling cerobong, sehingga membentuk seperti gunung berapi.

- Bakar serabut kelapa atau kertas Koran tadi jika sulit bisa ditambah sedikit minyak agar mudah terbakar.

- Api di dalam cerobong akan menjalar melalui lubang-lubang yang dibuat tadi dan menjalar membakar sekam.

- Jika bagian atas sudah menghitam / gosong aduk dari atas ke bawah agar bisa hangus merata. Proses pembakaran ini bertujuan agar sekam padi menghitam menjadi arang bukan menjadi abu, maka proses pembakaran harus selalu dipantau.

- Jika sudah menghitam rata/sudah menjadi arang, matikan bara api dengan cara menyiram dengan air. Ingat pastikan bara api benar-benar sudah padam. 
2) Briket

Pembuatan briket arang sekam memerlukan tiga proses tahapan. Proses pertama adalah membuat alat untuk membakar sekam padi (cerobong). Proses kedua adalah pembuatan arang sekam padi. Proses terakhir adalah proses pengolahan arang sekam menjadi briket bahan bakar/briket arang sekam padi.

Proses pertama dan kedua sama dengan pada proses pembuatan arang sekam sebagai media tanam. Proses ketiga, pembuatan arang sekam padi menjadi briket

Bahan dan alat:

- Arang sekam padi

- Bahan perekat (tanah liat / tepung kanji)

- Bambu / pipa paralon (diameter $10 \mathrm{~cm}$, tinggi $7 \mathrm{~cm}$ )

- Media penjemuran : papan / kayu / strimin kawat

\section{Cara pembuatan:}

- Encerkan 1 bagian tanah liat / tepung kanji dengan 9 bagian air.

- Ambil 1 bagian larutan yang terbentuk kemudian tambahkan 7 bagian arang sekam padi.

- Aduk hingga merata menjadi adonan yang siap untuk dicetak.

3) Pupuk cair

Bahan dan alat:

- Sekam padi

- Jerami

- Dedak

- Gula pasir

- EM-4

- Air

\section{Cara pembuatan:}

- Jerami dipotong sepanjang 5 - $10 \mathrm{~cm}$ sebanyak 20 bagian, sekam padi sebanyak 20 bagian, dedak sebanyak 1 bagian, gula pasir sebanyak 5 sendok makan, EM-4 sebanyak 5 sendok makan, air 20 liter.

- Larutkan EM-4 dan gula ke dalam air lalu masukkan ke dalam air 10 liter (1 ember) dan aduk secara merata.

- Jerami, sekam padi, arang sekam, dan dedak dicampur secara merata.

- Siramkan larutan EM-4 dan gula secara perlahan-lahan ke dalam adonan secara merata sampai kandungan air adonan mencapai 30\% (bila adonan dikepal dengan tangan, air tidak menetes dan bila kepalan tangan dilepas maka adonan kembali mengembang). 
ADMA

Deurnal Pengabdian dan Pemberdayaan Masyarakat
2022, Vol.2, No.2, pp.255-264

Doi: $10.30812 /$ adma.v2i2.1523

- Adonan digundukkan diatas lantai kering dengan minimal $15-20 \mathrm{~cm}$.

- Adonan ditutup dengan karung goni/ terpal selama 4-7 hari.

- Pertahankan agar suhu adonan antara 40-50 derajat celsius. Jika suhu terlalu tinggi, buka tutup lalu adonan dibolak-balik hingga suhunya turun. Pada suhu yang tinggi dapat mengakibatkan bokashi menjadi rusak karena terjadi proses pembusukan. Pengecekan suhu bisa dilakukan setiap lima jam. Setelah 4-7 hari tutup adonan dapat dibuka.

Proses pelatihan dan pendampingan ditunjukkan pada gambar 1 .

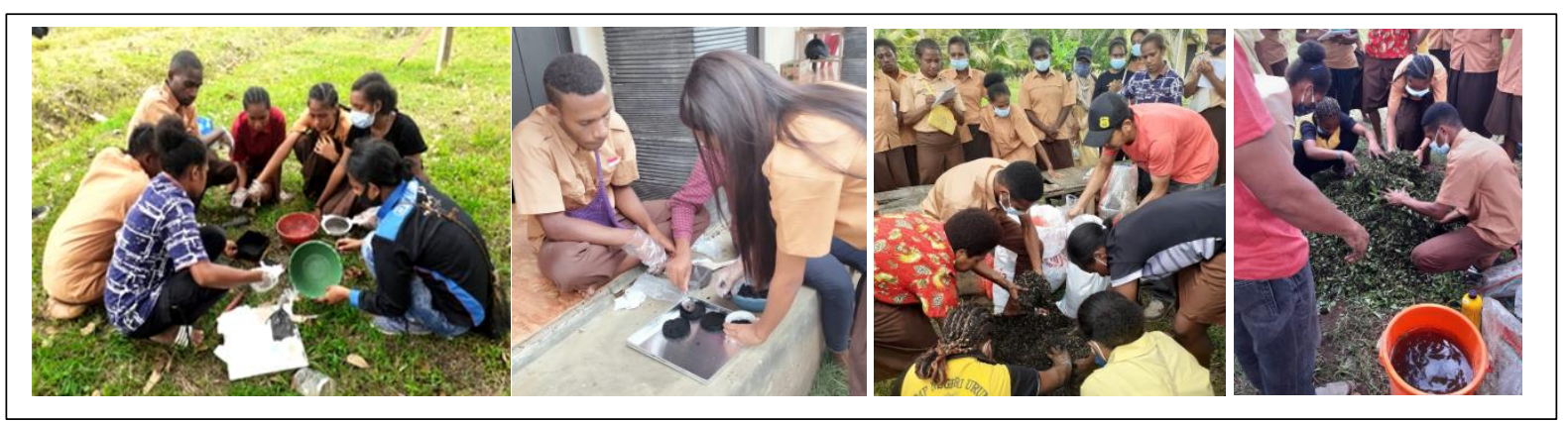

Gambar 1. Pelatihan dan pendampingan pemanfaatan limbah sekam padi

Sebelum pelatihan dilakukan pretest dan sesudah pelatihan dilakukan posttest Setelah itu dilakukan perhitungan nilai $\mathrm{N}$-gain. Normalized gain atau $\mathrm{N}$-gain bertujuan untuk mengetahui efektifitas penggunaan suatu metode atau perlakuan pada one group pretes postes design. Uji N-gain dilakukan dengan cara menghitung selisih antara nilai pretes dan nilai postes terhadap selisih nilai ideal dan nilai pretes (Yusuf, 2019). Data hasil tes dan Ngain dapat dilihat pada tabel 1 .

Tabel 1. Data hasil tes dan N-gain

\begin{tabular}{clc}
\hline No & Uraian & Jumlah \\
\hline 1 & Jumlah peserta & 25 \\
\hline 2 & Nilai rata-rata pretes & 57,04 \\
\hline 3 & Nilai rata-rata postes & 71,16 \\
\hline 4 & N-gain & 0,3287 \\
\hline
\end{tabular}

Tabel 1 menunjukkan bahwa jumlah peserta sebanyak 25 orang memperoleh nilai rata-rata pretes sebesar 57,04 . Hal ini disebabkan banyak peserta belum memahami cara pemanfaatan limbah sekam padi menjadi briket, media tanam, maupun pupuk cair. Setelah diberikan pelatihan dan pendampingan, nilai rata-rata postes meningkat menjadi 71,16 . Hal ini menunjukkan bahwa peserta mulai memahami cara-cara pemanfaatan limbah sekam padi. Selain itu dihitung pula nilai N-gain yang diperoleh pada skor 0,3287 . Skor ini berada pada 
kategori sedang, yang artinya pelatihan dan pendampingan yang dilakukan kepada peserta efektif dalam meningkatkan pemahaman peserta.

Dalam pelaksanaan pelatihan dan pendampingan, animo peserta sangat tinggi. Peserta senang karena dapat mempelajari hal baru dan menerapkan dalam kehidupan seharihari di sekolah. Perlu diketahui bahwa SMA ECA memiliki lahan perkebunan dan persawahannya sendiri, sehingga limbah sekam padi hasil swah, dat dimanfaatkan untuk menyuburkan lahan kebun. Hal ini berdampak pada peningkatan hasil kebun dan kemudian hasil ekonomi sekolah.

Hasil kegiatan ini juga didukung oleh hasil pengabdian masyarakat yang dipublikasikan oleh Terasne et al. (2021), Anggriani et al. (2021), dan Muhammad et al. (2021) yang menyatakan bahwa kegiatan pelatihan dan pendampingan, terlebih lagi pendampingan berkelanjutan, memberikan dampak positif berupa peiningkatan pemahaman dan keterampilan peserta.

\section{Kesimpulan}

Program ini mampu meningkatkan pengetahuan dan kemampuan masyarakat dalam mengolah limbah sekam padi, yang berdampak pada peningkatan kesehatan dan pendidikan masyarakat juga. Selain itu, program ini akan memberikan wawasan pengetahuan baru bagi siswa, serta memicu sikap kritis dan kreativitas siswa dalam memecahkan masalah di masyarakat sekitar.

\section{Ucapan Terimakasih}

Ucapan terimakasih diberikan kepada Rektor Universitas Musamus dan Ketua LPPM Universitas Musamus yang telah memberikan kesempatan dan mendanai pengabdian ini melalui Hibah Pengabdian Kepada Masyarakat Skim Pendampingan Desa Mitra DIPA UNMUS 2021. Ucapan terimakasih juga disampaikan kepada Pimpinan FKIP Universitas Musamus, rekan-rekan dosen dan mahasiswa yang telah bekerjasama dalam kegiatan pengabdian kepada masyarakat.

\section{Daftar Pustaka}

Admin. (2021). Pemanfaatan Limbah Sekam Menjadi Arang Sekam di BPP Banjar. Dinas Pertanian Pemerintah Kabupaten Buleleng. https://distan.bulelengkab.go.id/informasi/detail/berita/97pemanfaatan-limbah-sekam-menjadi-arang-sekam-di-bpp-banjar

Agung, G. F., Hanafie, M. R., \& Mardina, P. (2013). Ekstraksi Silika dari Abu Sekam Padi dengan Pelarut KOH. Konversi, 2(1). 
Anggriani, R., Abdurrahman, \& Ibrahim, I. D. K. (2021). Pelatihan Strategi Pemasaran Di Era New Normal Pada Kalangan Mahasiswa Fakultas Ekonomi Dan Bisnis Universitas Bumigora. ADMA : Jurnal Pengabdian Dan Pemberdayaan Masyarakat, 1(2), 91-98.

Bakhtiar, F. A. (2018). Pengembangan Aplikasi Berbasis Multimedia pada Pembelajaran Tematik Kelas III Sekolah Dasar. Mimbar Sekolah Dasar, 5(1), 16. https://doi.org/10.17509/mimbar-sd.v5i1.9363

Handayani, P. A., Nurjanah, E., \& Rengga, W. D. P. (2014). Pemanfaatan Limbah Abu Sekam Padi Menjadi Silika Gel. Jurnal Bahan Alam Terbarukan, 3(2).

Houston, D. . (1972). Rice Chemistry and Technology. American Association of Cereal Chemist, Inc.

Jasman. (2011). UJI COBA ARANG SEKAM PADI SEBAGAI MEDIA FILTRASI DALAM MENURUNKAN KADAR Fe PADA AIR SUMUR BOR DI ASRAMA JURUSAN KESEHATAN LINGKUNGAN MANADO. Jurnal Kesehatan Lingkungan, 1(1), 49-53. https://ejurnal.poltekkesmanado.ac.id/index.php/jkl/article/view/291

Muhammad, I., Hairani, Hammad, R., Irfan, P., \& Abd, K. L. (2021). Pelatihan Pembuatan Media Pembelajaran Bagi Guru MI NW Darussholohin Kalijaga dalam Rangka Meningkatkan Mutu Pembelajaran. ADMA : Jurnal Pengabdian Dan Pemberdayaan Masyarakat, 1(2), 135-142.

Terasne, Setianingsih, T., Hanan, A., Sukarni, S., Baiq, \& Nafisah, Z. (2021). Pelatihan Pengolahan Singkong Menjadi Keripik bagi Pemuda untuk Meningkatkan Kreatifitas di Masa Covid-19 di Desa Sukadana. ADMA : Jurnal Pengabdian Pemberdayaan Masyarakat, 2(1), 99-108.

Yusuf, M. (2019). Metode Penelitian Kuantitatif, Kualitatif \& Penelitian. Prenadamedia Group. 
ADMA

Gurnal Pengabdian dan Pemberdayaan Masyarakat
2022, Vol.2, No.2, pp.255-264

Doi: $10.30812 / a d m a . v 2 i 2.1523$ 